\title{
THE DOCTRINARY FRAMEWORK OF PHILOSOPHICAL TREATMENT
}

\author{
${ }^{1}$ Ş. Filiz, ${ }^{2}$ Zh. Zhanbayeva
}

\begin{abstract}
Being at the heart of all sciences, Philosophy is an understanding of thinking, knowing, enlightenment and practical life wisdom aimed at researching and enlightening the ways for human to be happy on earth, at the final point. In other words, it means to explore the ways and the methods to achieve eunoia, that is, "good thinking", "having a well-balanced mind" and finally "goodwill" and "kindness". For this reason, philosophy is the knowledge, wisdom and method of holistic thinking and action. Benefiting from the results of every science that studies all intellectual, emotional and behavioural accumulation of humanity individually within their borders, by their own methods, stems from the nature of this holistic approach of philosophy.
\end{abstract}

Keywords: Philosophy, Mind, Doctrine, Philosophical Treatment, Eunoia, Wisdom, Counselling.
${ }^{1}$ Akdeniz University, Antalya, Turkey

${ }^{2}$ Abai Kazakh National Pedagogical University, Almaty, Kazakhstan

Corresponding Author:

Zh. Zhanbayeva, zhanbaeva1988@mail.ru

Reference to this article:

Ş. Filiz, Zh. Zhanbayeva. The doctrinary framework of philosophical treatment // Adam alemi. - 2021. - No. 3 (89). - P. 3-15.

\section{Философиялық көзқарастың негізгі мәні}

Аннотация. Барлық ғылымдардың негізінде тұрған философия - ойлау, білім, ағартушылық және практикалық өмірлік даналықты түсінуді білдіреді, оның көмегімен адамзат жер бетінде бақытты бола алады. Басқаша айтқанда, бұл эвнояға жетудің жолдары мен әдістерін зерттеуді білдіреді, яғни «жақсы ойлау», «ақыл-ойдың теңгерімділігі» және «қайырымдылық» пен «мейірімділік». Осы себепті, философия - бұл білім, даналық және тұтас ойлау мен іс-әрекет әдісі. Адамзаттың барлық интеллектуалды, эмоционалды және мінез-құлық жинақтамаларын өз шекараларында жеке-жеке, өз әдістерін қолдана отырып зерттейтін әр ғылымның нәтижелерінің пайдасы философияға осы тұтас көзқарастың табиғатынан шығады.

Түйін сөздер: философия, ақыл, ілім, философиялық емдеу, эвноя, даналық, кеңес беру.

\section{Основное положение философского подхода}

Аннотация. Философия, лежащая в основе всех наук, представляет собой понимание мышления, знания, просвещения и практической жизненной мудрости, направленное на исследование и просвещение путей, с помощью которых человек может быть счастлив на земле, в конечной точке. Другими словами, это означает изучение путей и методов достижения эвнои, то есть «хорошего мышления», «хорошо уравновешенного ума» и, 
наконец, «доброжелательности» и «доброты». По этой причине философия - это знание, мудрость и метод целостного мышления и действия. Получение выгоды от результатов каждой науки, изучающей все интеллектуальные, эмоциональные и поведенческие накопления человечества индивидуально в пределах их границ, своими собственными методами, проистекает из природы этого целостного философского подхода.

Ключевые слова: философия, разум, доктрина, философское рассмотрение, эвноя, мудрость, консультирование.

\section{Introduction to Philosophical Treatment}

In this sense, philosophy cannot regard analysing the individual forms of human culture sufficient, itself. It seeks a view with a universal synthesis (synthetic) that covers all individual forms. Rumour, religion, art, language, and even science are now regarded as variations of a common theme. The task of philosophy is to make this theme known and understandable [1].

In the 20th century, psychology had a privileged place in solving the problems of humanity, despite serious contradictions in its search of methods. According to Lahav and Tillmans, psychological therapies are quite different from philosophical treatment. However, differing them from each other is a troublesome task. This distinction is still not fully achieved. According to Lydia Amir, philosophical practice is not necessarily against psychology or psychologists. Philosophical practisers usually imitate psycho treatment. Philosophical Coaching requires an interdisciplinary perspective [2].

The doctrinal framework of philosophical treatment consists of the definition, target and target group of the treatment, its content and how it is applied. The doctrine, theoretically and practically consists of two main categories. The type of the application of the treatment right after the theoretical framework drawn, the method of the application of the treatment will be explained as: first the explanation of the method is practised, treatment prospective, the ones who can apply the treatment, the effect mechanism of the treatment and usage of the treatment.

\section{Methods}

Within the framework of this method, a doctrinal framework of philosophical counselling is created for the first time. Philosophical counselling explores the theoretical and practical possibilities of philosophy to ensure the interaction and coordination between impulse, emotion and thought; it establishes a balance between thought and action and offers a healthy way of thinking. According to this doctrine, philosophical counselling creates a new philosophy theory based on the scientific level of our age and a philosophical practice based on it. Theory and practice make it possible not to cure medical disease, but to ensure and sustain the health of thought by making use of scientific foundations. Philosophical counselling doctrine focuses on both spiritual and mental healing; in cooperation with psychology, psychiatry and psychoanalysis, it aims to pre-treat mental illnesses with the methods of healthy thinking.

\section{The Definition of Philosophical Treatment}

What does philosophical treatment mean?

Philosophical treatment, firstaims to treat all people, on the common base, without exception, against the existential and vital problems. Philosophical Treatment predicts the target of contributing human/humanity to be made up of individuals who think and live wisely, by means of reproducing and interpreting cultural elements such as science, culture, art, religion, politics, which are accumulating, going on to accumulate 
throughout the history of philosophy, as the preserving treatment, in order to prevent the individuals be potentially sick mentally, spiritually or physically [3].

Definition: Philosophy is above all the dialogue with life [4]. Philosophical treatment is the application of all the historical, cultural and ethical accumulations of philosophy to the situation be therapized, by means of making mental and spiritual analysis of reflected existential and vital situations (problems or gaps), which reflect on emotions, thoughts and attitudes of individuals, 'in normal and healthy process' before mental, spiritual and physical medical symptoms appear and eventually diagnosed as 'disease' [5]. Birth-death trauma, existential issues such as the meaning of existence and life and situations ranging from purpose and meaning to life, forms the scope be studied in the philosophical treatment field. These problems or gaps for philosophical treatment are not diseases, but existential and vital issues shared by all people. I don't regard them as the subject, because, seeing it solely as a problem or a gap, comes to mean to consider all people philosophically 'problematic', moreover 'patient', even if not medically. Whereas, according to the philosophical treatment doctrine, people who will be applied philosophical treatment are not 'sick' or 'problematic'. However, turning the universal human situations resulting from the nature of existence and life into 'space' and 'problem' are pathogenic processes going wrong and eventually lead to illness that philosophical treatment should solve.

\section{How is philosophical treatment applied?}

In ancient times, Socrates made philosophy with the Athenians he met in the Agora, on the issues that concern their daily life and led them to rethink what they consider to be true information and had them question the validity of his thoughts to them. We encounter concrete examples of what we call philosophical treatment in
Greek and Roman philosophies. Cynics, Stoics or Epicureans regarded philosophy as the teaching of the art of living rather than teaching the abstract theories. In this framework, Ancient philosophy schools aiming to direct the right age individuals to the right lifestyle and to teach them how to deal with their personal distress / problems are counted as the first examples of philosophical treatment schools. In addition existentialist therapy, which derives from Existentialist philosophy, the Stoic bases of phenomenological and rational Emotive Behaviour Therapy of Gestalt therapy are encouraging that it can serve as a basis for philosophical treatment [15].

Philosophical treatment is not just a philosophical activity. Although it is not experimental, it proceeds on the given and concrete level of dialogue between the consultant (hereinafter called homoogenics) and the client. Although homoogenics cannot ask the special situation with general philosophical concepts, philo-ogenics (consulted, philosophical therapist) puts given situation into general philosophical concepts; and so it solves the special situation of homo-ogenics. During philosophical treatment, homo-ogenics is autonomous and it is paid her/him be autonomous.

\section{What is the object of philosophical treatment? \\ Object: Philosophical treatment is} the view of homo-ogenics to life, the meaning he put on it and the emotions and thoughts expressed by him. Even though, the thoughts and feelings that he did not express clearly are the object of treatment. What Lahav calls philosophical self-investigation is the analysis of the ideas that homo-ogenics can consciously put into words. The rationale for this approach is that although philosophical treatment explains that one should stay away from the subconscious causes [16], her emotional states or problems arising from the psychological mechanisms that are accepted to occur in the person, 
philosophy cannot stay away from psychology born from her. Philo-ogenic, when necessary, can expand the treatment by acquiring the necessary hardware for psychological analysis. The definition of philosophical treatment or counselling is baseless, remaining within a pure field of philosophy that will not intersect with the field of psychology. Although philoogenics's field of work for treatment is philosophy, it is not correct to limit philosophy likewise. Because making the familiar understanding the object of philosophical understanding means subjecting the first to deeper and more comprehensive analysis [15].

Philosophical treatment takes the object of misconceptions, dysfunctional and inconsistent thoughts, possible emotions and attitudes that may always come out of the control and valid for us. Philosophical treatment is not essentially experimental, it has no prescription ready and it produces original discourses.

Homo-ogenics is expected to understand him not to overcome. Because no matter how broader the boundaries are, the existential boundaries of each individual are certain. The problem is not to cross existing borders, but to find them. Philosophical treatment is done to show us our existential and vital boundaries, which we know but are not aware of.

This is acceptable if the exceeding of man is, as Lahav says [7], exceeding the usual understanding of man. It is essential to help to find the meaning and critically analyse the view of life developed according to the existence, but not having a new existence with a personal journey towards wisdom in the sense of being open to the network of rich thoughts determining life. There may be a new view of life and a new meaning, but a new existence is not ontologically possible. At this stage, as Lahav rightly pointed out [7] the role of philo-ogenics is to confront homo-ogenics world-life view, help him critically question the world-view of life and to allow him to go beyond his existing understanding and insights and to establish a new world of meaning.

Philosophical treatment cannot be separated from academic and applied philosophy.

\section{Philosophical Treatment Method}

Method: Philosophical treatment is primarily a way of dealing with concepts. Discussions on the meanings loaded on the concepts are done in order to reveal homo-ogenics' (In the quoted text, instead of "the client", I used the term of mine "homo-ogenics" and "Philogenics" Instead of "consultant") not understanding philosophically, see the hidden aspects of the things they do not know in their worldlife views, and with respect to this going into the depth aspects of the problems and facing them and to learn how to deal with them and to deal with them. Philo-ogenics help homo-ogenics understand the causes of their problems by using philosophical thinking tools such as: world-life view interpretation, existential analysis, critical thinking, linguistic and conceptual analysis, empathic listening, concept analysis, and phenomenological investigations are among the methods of philosophical treatment. Some of the techniques used in philosophical treatment are dialogue, world-life view analysis, problem-oriented approach, person-oriented approach, open-ended investigation, closed-ended investigation, autonomous homo-ogenics approach and intervening philo-ogenics approach. Although philo-ogenics uses Achenbach's 'post-method method' or any other method, to reveal and question, in the focus of a philosophical treatment there is always a way to find out and crack the world-life view of homo-ogenics in all aspects even hidden for himself, and the next step replacing this cracked world-life view by a new philosophical understanding. The technique used in this process is the dialogue technique [7]. 


\section{Its Target and the Target Group}

There is a difference between the person that the logo-therapy wants to achieve and the person we want to achieve. The one of logo-therapy is improved human model and what we want to achieve is a homoögenic person.

The homo-ogenics method refers to the 'Large and Average Human Community' (LAHC). This community has general human existence and general laws of natural life. This corresponds to a general existential and vital well being. This part constituting the majority of people compared to the superhuman and subhuman parts, also acts a source of other 'diseased' segments we refer to. This concept of 'disease' that goes beyond the subject of philosophical treatment is evaluated in medical and judicial categories and philo-ogenics (abbreviated as FJ) treats in case of skidding to IS and IAS. Because only the people or groups that were in the interest of the forensic and medical categories belonged to the 'big piece', earlier. Homo-ogenics method is responsible for 1 . Protecting the homo-eugenic category against skidding and ruptures with treatment, 2 . Working on dynamics to control swings and breaks, and is responsible for investigating the reasons for this and investigating the reasons for this, against the losses experienced or may be experienced by being thrown into the lower or upper categories. Because without philosophical treatment, these breaks can become accelerated, uncontrolled and even common enough to create a sense of general acceptance. Each $\mathrm{HJ}$ is a homoogenics sample taken from the large piece.

LAHC is the natural source of the lower and upper categories, in another saying, the groups closer to being medical and forensic cases. Separations from LNHC, without philosophical treatment, becomes unavoidable melting $\mathrm{LNHC}$ at an uncontrolled rate and continuously and downsizing it in favour of the lower and upper categories. Philosophical treatment

controls these breaks; investigates its causes and consequences; It makes things workable using the homo-ogenics methods in order make the LNHC sustainable. Let me explain with a concrete example: Water resources in nature are taken under protection by dams, natural sets and a number of power plants to be offered to the service of people. Dams prevent both loss; and the water in it is processed through various processes to a healthy consistency that people can drink. Otherwise, the vast majority of water will flow and waste in nature; it will not only be wasted, but also will cause landslides where it flows, will damage cultivated land, and may even cause soil loss. In addition, people will desperately use the natural left water in the nature, as it is not kept in a healthy place, it may threaten human health.

Now the water kept in the dam is LNHC. Despite this, the water flowing to nature is scarce and it is flows in a controlled manner. Therefore, it does not harm nature or human. Regarding this example, the water held in the dam represents the large target group of philosophical treatment in terms of preserving and processing it to become healthy water. Water leak represents the upper and lower people. Though people in both categories are closer to forensic and medical treatment, they cannot harm and destroy LNHC. Just as small water leaking out of the dam cannot spoil the currents, LNHC is protected against the damage of the lower and upper groups separated from itself thanks to its philosophical treatment dam. Otherwise, leaks at the top and bottom will multiply; this does not only make LNHC smaller, but also makes the others in the group resemble them. People who appear in LNHC, but mainly are in the lower or upper categories, after a while, liken LNHC to their own categories. This tells us about individual and social decay.

We can reproduce samples in different ways. 
Homo-ogenics person corresponds to this big part. There are existential and vital laws that apply to all personal, social and natural people, and all those subject to these laws are homo-ogenics. However, each individual of the big piece perceives and applies these laws with their own subjectivity in their existence and life. If these differences turn therefore mentioned laws into judicial or medical case beyond the limits of interpreting and implementing the person with forensic and medical subjectivity, then $s /$ he is broken off and the philosophical treatment cannot be applied. The general legality before this break and accordingly providing the existential and vital balance between the individual subjectivity, he main focus of the philosophical treatment, that we call homo-ogenics. 1. Thinking education and order. 2. Enlightenment journey from knowledge to wisdom are included in this method.

According to Philosophical Treatment or homo-ogenics philosophical treatment doctrine, human existence is divided into three main categories:

Superhuman (TH): It refers to a category that is accepted or believed that this type it is existentially or materially over the average person, other normal people. For example, people who form the upper economic class, who have reached a certain economic level, and can easily obtain all their financial needs by using their possibilities, are categorized here. The other variant of this category, for example, is the type of human who regards him as spiritual as the upper human, such as the wizard, the prophet, the guardian, the sheikh, the Saint, and people who are regarded this kind in the society.

As seen in both categories of superhuman beings, both materially and spiritually are closer to both existential and vital space. For example, since people who have all kinds of financial possibilities think that they have the power to get everything, they: a. Fall into existential lackness being in boredom,

b. Fall into a vital emptiness because they don't have possibility of contact with the other but large face of life, that is, situations such as pain, absence, sadness, death, which the big mass of people suffer. This top-person is a part separating from normal people. The treatment of people in this group can be done, only if they suffer from the condition they are in and demand to get rid of this gap. People, who regard themselves above the "large and Average human community" (LAHC) in its abbreviated form, and are wrapped and titled in superhuman adjectives are priests, wizards, sheikhs, murshits, priests, yalvacs, monks and so on.

Sub-human Human (SHH): this category, like superhuman, is a piece that is separated from the 'Average human' mass. Viktor E. Frankl is the first psychiatrist to use this term. [8] Sub-human human is the one, who have not received enough basic cultural ethical and social values in the process of humanization; mostly focusing on biological creature features and in an instinctive life. Therefore sub-human human;

a. Though being like other living things, as he is different from them with his developed consciousness and he solely focuses on sustaining his biological life, he still suffers from boredom and falls into existential space.

b. S/he suffers the vital emptiness, since $s /$ he does not have an interactive and cultural life.

c. SHH comes to mean ordinary but intelligent creatures having no special features other than maintaining his/her biological existence. Although these are the normal, in all these categories; from psychopaths, slaughterers, paedophilia, crime machines, those who are mentally imbalanced to people those who make direct harm to people, living things and the environment a natural part of their life, make up sub-human groups.

The types of people in both categories 
mentioned are pathogenic, although the conditions they live in are not pathological. Their differing from the average human starts the pathological process in the first plan. Once having separated, it becomes more likely that the categories in which they are located will throw them into the pathological process. Unless there is a medical and judicial situation, people or communities forming the sub-human group are also subject to philosophical treatment. It needs to emphasize that, unless there are medical and forensic situations, philosophical treatment is applied to all three groups according to the decided treatment levels. FJ does not intervene in forensic and medical cases; however, searches for the treatment possibilities before and after.

Human or "Average Human" (OS): The category of people that philosophical treatment will work on is the average human. In other words, the average man in this category, which constitutes medically the 'normal and healthy' majority, as the top and sub-human categories needs a philosophical treatment against the parts that will be separated from himself/herself. In other words, philosophical treatment does not accept those who are blown from the average mass of people to the lower and upper categories of people.

"Large and Average human community" is LAHC. The superhuman and sub-human breaks are out of this mass. The sub and top categories are small pieces broken off from these large categories. Unless they are dealed by homo-ogenic philosophical treatment, the large part will constantly melt in favour of the top and sub parts.

The person who is the addressee of philosophical treatment is in the category that constitutes a large and normal majority compared to other human categories.

The main purpose of philosophical treatment is to work on this average human to take precautions against both existential space and vital space in order to prevent the division of the sub and top human and to experience losses. The average human combines the characteristics of people in the lower and upper categories. In other words, s/he is a biological creature on one hand, and a cultural entity on the other; but, balancing both mentally and culturally, combines the both together. Keeping the combination in balance is the main goal of philosophical treatment.

The average person has a complex entity structure. The complex entity can be managed through philosophical treatment, which proposes a complex method. When we say question what the structure of the complex being is; man is a two-layered being. He is born, grows, feed, breeds, gives birth, faces and dies with his biological presence. All other creatures do the same. His biological life is uniform and simple like other living things. However, the first reason of his being and his existence is his ability to create symbols.

However, having this capability is not enough to humanize both ontologically and ethically. As Ernest Cassirer claimed, the definition of a human existence potentially linked to such a talent is a substantial definition [1], however; this second kind of existence that creates cultural symbols cannot be understood with the substantial definitions. If this category of average human is normal and "medically healthy", why is philosophical treatment needed?

The average human is medically not ill or does not require treatment and they form a great number of people, who do not conform to the definition of 'patient'. Most people who are closest to or within the treatment boundaries of medicine fall into the other two categories. Since philosophical treatment is not a medical treatment or psychiatric improvement, it will naturally interest to the average human, not the other two categories. Philosophical treatment starting with a philosophical method, not a medical method, has great possibilities both to benefit from the medical field and to benefit from the medicine itself. Because 
all sciences are born from philosophy, philosophical treatment does not go against any scientific method or medical treatment. We call the concentration of philosophical treatment on the average human being homo-ogenics. In other words, it is another name for philosophical treatment. It must have a presence in both biological and cultural aspect.

Our first step is to develop him from sub-human to average human. Subhuman is a clever animal that does not have any feature other than maintaining his biological existence. The clever animal goes up and seems a clever person. Because the clever animal is the one getting rid of instinctive shallows of all animals with his own intelligence and a sub-stage threatening the community at the human level. In order to pass this substage, he needs philosophical treatment. So what can be done for this?

Human is a high being with the culture. Language, religion, tradition and custom include all of them. It reaches the upper person, shaped by all these elements. Philosophy defines the human as a purely cultural entity, too. All others apart from it are just biological beings.

The average human means the average life.

Philosophical treatment aims at the average life. It targets the middle of death, life and everything. Golden Mean (Aristotle) [6]. The sub-human concept is not an acceptable concept for philosophy. Likewise, the superhuman concept is not an acceptable concept, either. In his book of the origins of the Greek philosophy thinking, he says that the clergy, priests, prophets have a relationship, this way or that way, with philosophy. This is an abnormal situation, coming out of abnormality and becoming normal is thanks to philosophy. This is actually a treatment problem. When this happens, the following comes to mind; when we cannot get the concept of the human in which the average of life is embodied, we can be scattered either to sub-human or superhuman.

Since homo-ogenics conditions are universal general human problems, appropriate and right treatment is philosophical treatment. Every conflict is not necessarily neurotic. Even to some extent, conflict is normal and healthy. Similarly, suffering is not always a pathological condition. What does it mean to be at the Average human man level? Actually performing for others and taking action for the benefit of others, man can only realize his own existence. In a more general context, existential and vital space is not pathological in itself. However, it can also be pathogenic. So homo-ogenics existentialism means to exist for others rather than him. This shows us that we should take advantage of the interactive model of Turgay Sehil, which he has briefly called the IUM, the Interactional Universality Model [9]. Interactivity is our communication with people out of us. So you both know yourself and know others. But if you stop the relationship with other people and only take care of yourself, you can not only recognize yourself but also know others.

Then homogeneous existentialism is an extrovert existence. Sub-human existence is an existential deficiency. It is defined as the irrelevance. The stage of being human is a critical and tense stage. If were the doctrine we call philosophical treatment not for human, it would not be very dynamic. Here, philosophical treatment takes existential dynamism from the concept, which is existential. Philosophical treatment takes its existential dynamism from the concept of being human. The sub-moon universe is where the body, that is, where there are the temporary creatures. But mentally and spiritually, we are members of the topmoon universe. However, we cannot feel ourselves peaceful, neither in the sub-moon universe or the top-moon universe. We are somewhere in between the both. Being human means being in-between. So, if we say "where we wish to arrive at", it comes to 
mean that we want to stay as a human and to gain the ability to sustain our existence. The reason why we are in between has to copy both the pain and the joy, and spiritual and body both. This means being obliged to represent both stages and owing to life. The existential and vital homo-ogenic method of being indebted to life will open up ways to turn life into art. It is the FJ that will implement this method on the HJs. It should be noted that FJs are also HJs; the difference from HJs is that they realize their being HJs. That doctors cannot treat every disease and refer to another colleague, is similar to this.

The homo-ogenic treatment method encompasses all three categories of people - unless medical and judicial intervention is required. The homo-eugenic treatment method is planned to have a positive effect on people in any category without having any biological and functional problems.

\section{The Content of Philosophical Treatment}

So, what are existential problems or existential emtiness?

Birth trauma comes the first.

Otto Rank describes birth as a trauma [10]. At the other end of the birth, there is the death trauma, in which fear and anxiety of death are concretized. Death is the greatest pain, sadness and, in short, a trauma in human life. Todd May claims that immortality is a trauma as well as a sense of mortality and anxiety [11]. According to him, immortality is, even, more anxious than mortality. Human beings have anxiety about the future, not only as a living creature in advanced nervous system, but as a spiritual being [12]. The future raises the problem of unknown and obscurity. $\mathrm{He}$ starts to be enstranged to himself, around him and the nature. Leaving his wife, friends, and family because of death or leaving, loneliness and the feeling of being worthless trigger each other directly or indirectly. Fear of death and anxiety prepare the fear of disease.
Aristotle focused on people and their emotions in detail. According to him, enthusiasm is emotions that change people's judgment enough to affect them, on one side, but also accompanied with pain or pleasure, on the other side. The human gets angry in case of illness, poverty, frustration, thirst or tiredness. Aristotle gave detailed answers to the question of whom or what one gets angry. He listed the opposite feelings of the conditions for the emergence of joy. He describes the fear using the feelings of calmness, seriousness, friendship, hostility, grudge and hatred and fear; tells the reasons and interlocutors [13]. Almost all of works of Aristotle can be used as a source for Philosophical treatment.

While Descartes processes and analyzes the ambitions, emotions or moods of the human spirit in detail, he mainly includes existential issues and vital problems. Emotions of the spirit for him; are its perceptions, feelings or excitement. Emotion is a picture of the situation that the human is in. The human body reflects these emotions with behaviours such as sweating, blushing, relaxation or spasm. They can clash although when they are compatible with each other. Both the goodness of the soul and the harmfulness of the soul can be kept alive. According to Descartes, six basic feelings can be mentioned. These are amazement, lovehate, desire and joy-grief. Wonder is the sudden surprise that causes the spirit to look carefully at objects that are rare and unusual for it. Love is the desire to get closer to what the soul regards close for it. Hate is a departure [14]. While grief is an unpleasant numbness case, joy is a sweet excitement.

The present analyzes of Descartes can be used in treatment [14].

Existential space or existential problems arise at the stage of self-perception and self-knowledge. Philosophical treatment first begins at this stage. Human want to relate to all objects surrounding 
themselves, especially being their existence prominently, through their senses. His biological-mechanical existence, his first nature, was given to him by birth. It is thanks to this first nature that he lives alive. Just like other creatures, the body depends on eating-drinking, reproduction, defecation and similar biology-mechanical processes. Since his sufficiency to live content with the given nature, will make it compulsory to share the same habitat with other creatures, it will be at risk even just meeting his physical needs and under no circumstances he cannot live with other creatures as a "clever creature". This defines the sub-human existence. The superhuman stage is also not convenient to survive just as a living being. Because he cannot meet the needs for both a living being and a superhuman spiritual being at the same time. He cannot survive in the superhuman spiritual field by breaking off his "humanitarian" existence. Because, the superhuman situation and sub-human situation do not fulfill the requirements of humanistic existence and humanization. In both cases, existential emptiness occurs. In the first case, just being alive is not enough to make him human. In the second case, it is not possible to be alive but keep away from both living and biological requirements. $\mathrm{He}$ must try not to fall into the both situations, in order to continue the "humanization" process, in the way as producing culture in the information universe and reproducing his existence with every unit of culture (language, art, science, economy, religion, literature, painting, music, etc.), making it sensible and raising awareness. Supporting this effort is the goal of philosophical treatment.

How is human being humanized? Sense organs are the gates of man opening to the outside world. The phenomenon of Helen Keller proves that being deprived of these organs makes the person hurt, upsetting his life and dragging him to the misery. People with healthy senses even may have to undertake the dark world of the Little Helen, and go on unhappy and dark life, because of not using or misusing those organs. The life story, handling Helen Keller as a case, shows the practice of how seeing with concepts can transform the human nervous system.

Sehil who commented on the case, while evaluating Helen's practice, in a process from impulse to consciousness, from object names to concepts, emotion and behaviour, and comparing his Universal Interactivity Model, he mentions in his work of "Journey to Freedom", he gives important clues about how philosophical treatment can walk through consciousness:

The fact that we humans cannot understand the universe we live in is very similar to the situation in which little Helen fell into it. She wants us to imagine a ship sailing through white fog so we can understand what kind of world Helen lives in. But we are also in a fog that surrounds us. Since the concepts about the huge space surrounding our sky have not been formed in our brains yet, we cannot see the space. It is not enough to look at the huge darkness of the universe or the sky islands within it. There is something connecting them, but we cannot see this space we are looking at. Little Helen was always beginning to see with the concepts of what she touched only and she could create in her brain and relate to each other. In order for us to see the space that relates the universe, we need concepts that we can create in our brains, and relate to each other. I think these concepts will be shaped by means of understanding the consciousness phenomenon. I think that as long as we grasp the phenomenon of consciousness, we will learn the fact that the beings in the universe are related one another, no matter how far they are from each other, and that way we will learn our place in space then.

In fact, this is how a universe with an absolute consciousness develops from an unconscious universe.

In another way, the universe reaches a structure that determines, activates

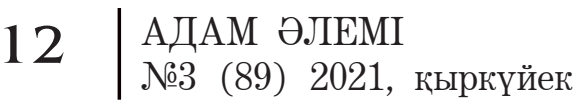


and becomes more and more liberated structure. An universe that can influence every interaction of space-time, from an unconscious universe of inorganic interactions to absolute consciousness through conscious interactions is taking place. The experience gained by each individual and the awareness created contributes to this development and transformation in the universe. It contributes to universal consciousness, with the behaviour that we call awareness, with the contribution that can be expressed as individual consciousness, in other words. Each individual adds his awareness, that is, his experience, to the development of universal consciousness. The entity, which we describe as a society, occurs through the transformation that takes place on this transformation. The individual, for this reason, becomes the building block of societies and causes societies to find existence. In this way, societies can influence people through their behaviours, in space-time. Thanks to the behaviours of societies, new forms of behaviour occur in the universe and societies cause new entities to emerge. Considering societies' vehicles of observing space and the ability of societies to send explorer tools to the depths of space, the activities of the entities created by the society, in space-time, reach an unimaginable level [9].

Loss of sense organs or their being not functional enough even if he is healthy means, at first glance, we are deprived of sensory information the phenomenon of knowledge related to the senses. However, deprivation does not remain at this point; it leads to existential space. We cannot reach any information about the outside world when our contact with objects is interrupted. Epictetos (135 BC) [15] emphasizes "of someone's condition having the sense and pretends it's not there is worse than the death". Since, knowledge is the first thing that comes out with sensory interaction and it is the door of interaction, the first step to knowledge starts this way. Helen's condition was "worse than the death" for reasons she could not handle. She seemed gruff, her balance was shaken, and she was in great despair and almost lost her mind. If the teacher had not rescued Sullivan, her family had even considered taking her to a mental hospital.

Having lost her ability to hear, see and speak at a young age, Helen created concepts by learning the names of objects with the help of her teacher Sullivan, and the development continued throughout her life. The concepts we acquire with the emotions and thoughts we have, are the keys to obtain information, which are vital as much as our biological needs, and even more vital than them. The need to interact with the outside world, including ourselves, first, embodied in the information. If there is no information, no emotions, thoughts or behaviours happen in a healthy way. For this reason, I named the philosophical therapist as Philo-ogenics, that is, the information creator.

\section{Conclusion}

Every name is the gateway to a new thinking. Every object touched is filled with life; the mystery and meaning of life are revealed with these touches. Little Helen fought with the limits narrowed by the senses she lacked and reached the happiness of exceeding them. In order to access the information universe, it is in our hands to get rid of the world we are imprisoned in, just like the creature cracking and going out of its shell. We can achieve this liberation with philosophical treatment. Philosophy is in life. Life dynamism is activated with the impulse created by the philosophical questions. The process of recognizing objects that result in incentive, emotion, thought, knowledge, and finally behaviour begins with the formation of the concepts in the brain.

Concepts formed in the brain and changes, which are formed with the 
interaction of these concepts, in the nervous system with the production of information, definitely forms behaviour differences in the person. In other words, the more precisely the existential problems are detected in the first step, it comes to mean, for the solution of the second stage, vital problems, the less time and effort will be spent.

This way in the first stage where existential problems exist, the emotions and thoughts we have are indispensable for our lives. It humanizes us, and differs from the other living things. It offers us a different life. It gives us hope via freeing us. Not only does it offer us possibility to change and transform; but also makes it easy for us to notice the limits.

Here the most important stage for the problem of self-perception and recognition are concepts being in relation to objects that occur in our brains, allowing us to connect senses and objects.

The problem of not knowing how to ask for what, why and how, is the second example of existential space. This problem arises from the fact that one does not have enough ideas about himself. So, as Socrates stated centuries ago, man has to know himself before he has known the world around him. The person who knows himself has the opportunity to find clearer answers to what he has weaknesses in, why he is afraid, what he can and cannot do.

The problem of positioning oneself in nature, society and family means the problem of belonging. His work, family and social environment are natural and human habitats that surround around people. The problem of what, why and how he likes or dislikes, is the problem about what answers one gives and why he answers this way, for the questions hidden or clear, he asks about himself and the cause of life. In fact, the actual life of each individual is the answer to a number of questions that everyone is asks but most of them are not aware of. At this point, comparing the questions and answers, it is confirmed one's actual life and world-life view of the conceptualization of Ran Lahav [16].

Neuro-ogenics symptoms arising from not being at peace with life and being afraid of death and the stage before turning into neural problems, is the stage of philosophical treatment. Since we have learned that we have learned that not being at peace with life and being afraid of death can have neuro-ogenics symptoms, the previous stage is the field of existential problems that philosophical treatment should involve in.

The problem of emotional confusion necessitates us to identify which emotions are active or passive in the process driving from incentive to behaviour. As identification problem with habits "the human is the sum of humanistic habits" aphorism has pointed out, people define their own existence and life in accordance with the habits they have acquired; set their limits and express themselves, before they have realized. While some of the existentialist philosophers describe existence according to the core, that is, the constant feature or properties that human beings are born with and form his identity (for example, Gabriel Marcel, Kierkegaard, Karl Jaspers), others say that it is the actions of the person constructing his existence (for example, Jean Paul Sartre, Heidegger). Whether innate or acquired later, all habits can become synonymous in human existence over time. This, however, can cause a number of philosophical diseases (besides medical and forensic cases).

The problem of difficulty in keeping the balance between opposite emotions such as courage-fear, pleasure-pain, joy-sadness, excitement-coolness and external causes affecting the nervous system (wealthpoverty, hostility-friendship, strongnessweakness, disasters-good news etc.) may lead to the collision of emotions within us and to the victory of one or the other. This adds some problems to human existence and life.

The problem of nihilism, which is 
a common private and personal mass neurosis in our age, refers the target community of philosophical treatment, namely the homo-ogenics, normal and large majority.

The existential space or existential problems can be expanded through the practice of philosophical treatment within the framework of these basic determinations.

\section{References}

1 Cassirer E., İnsan Üstüne Bir Deneme. (Çev. Necla Arat). - İstanbul, 1997. - 96-97 pp. (in Turkish).

2 Lizeng Z., Distinguishing Philosophical Counselling from Psychotherapy [Philosophical Practice]. - 2013. - N 8(1), 1121-1126 pp.

3 Filiz Ş., Felsefi Sağaltım [Pales Yayinlari]. - İstanbul, 2018. - 31 p.

4 Mehuron K. Supervision and Case Notes in Philosophical Counselling Practice (Philosophical Practice: Journal the American Philosophical Practice Associaton). - 2009. - N 4(2). - 467-474 pp. (In Eng).

5 Altunbasak i.., What is Philosophical in Philosophical Counselling? [FLSF The Magazine of Philosophy and Social Sciences]. - 2019. - N 27, 409-426 pp.

6 Kaynak Iltar, E. Aristoteles'in Ahlak Öğretisinde Yer Alan "Mesos Kavramının
Tüm Felsefesi Üzerindeki Etkisine İlişkin Bir Değerlendirme" [Eurasian Conference on Language and Social Sciences]. - 2018, 42 pp. (in Turkish).

7 Altunbaşak İ. Nermi Uygur's Reconcilation With his Depression As a Philosophical Counseling Method. [ Posseible Thought Magazine]. - 2018, N 14. - 77-98 pp.

8 Frankl E.V. İnsanın Anlam Arayışı. (Çev. S. Budak). - İstanbul, 2019. - 45-60 pp. (in Turkish).

9 Sehil T. Özgürlüğe Yolculuk. - İzmir, Duvar, 2018. -35-70 pp. (in Turkish).

10 Rank O. Doğum Travması. (Çev. S. Yücesoy). - İstanbul, YKY, 2017. -15-27 pp. (in Turkish)

11 https://www.iremyalugulubil.com/tr/ article/desc/46569/kayip-yas-olum-ve.html (Date Acc. 30705.2021), (in Turkish).

12 May T. Ölüm. (Çev. Emre Keser). - İstanbul, Say, 2019. - 57-94 pp. (in Turkish).

13 Aristoteles Retorik. (Çev. Mehmet $\mathrm{H}$. Doğan). - İstanbul, YKY, 17th Edition, 2019. 35-47 pp. (in Turkish).

14 Descartes. Duygular ya da Ruh Halleri (Çev. Çiğdem Dürüşken). - İstanbul, Alfa, 2015. - 64-163 pp. (in Turkish).

15 Altunbaşak $i$. What is Philosophical in Philosophical Counselling? [FLSF The Magazine of Philosophy and Social Sciences. - 2019, N 27, 409-426 pp.

16 Lahav R., "What is Philosphical in Philosophical Counselling?", [Journal of Applied Philosophy]. - 2019, N 13, 259-78 119a, 267 p.

\section{INFORMATION ABOUT AUTHORS}

Şahin Filiz

Zhanat Zhanbayeva

Шахин Филиз

Жанат Жанбаева

Шахин Филиз

Жанат Жанбаева
Professor, Doctor of Philosophy, Akdeniz University, Antalya, Turkey, sfiliz@akdeniz.edu.tr, karabagsahin@gmail.com. ORCID ID:00000002-4249-22-21

PhD Student, Abai Kazakh National Pedagogical University, Almaty, Kazakhstan, zhanbaeva1988@mail.ru ORCID ID: 0000-0001-6610-3190

Профессор, PhD, Ақтеңіз университеті, Анталия, Түркия, sfiliz@akdeniz. edu.tr, karabagsahin@gmail.com. ORCID ID:0000-0002-4249-22-21

PhD докторант, Абай атындағы Қазақ ұлттық педагогикалық университеті, Алматы, Қазақстан, zhanbaeva1988@mail.ru ORCID ID: 0000-0001-6610-3190

Профессор, PhD, университет Ақдениз, Анталия, Турция, sfiliz@akdeniz. edu.tr, karabagsahin@gmail.com. ORCID ID:0000-0002-4249-22-21

$\mathrm{PhD}$ докторант, Казахский национальный педагогический университет имени Абая, Алматы, Казахстан, zhanbaeva1988@mail. ru ORCID ID: 0000-0001-6610-3190 